\title{
IMPROVING STUDENT'S MATHEMATICAL CREATIVE THINKING ABILITY AND SELF REGULATED LEARNING USING SYLVER APPROACH
}

\author{
Desy Tri Damayanti ${ }^{1}$, Utari Sumarmo $^{2}$, Rippi Maya ${ }^{3}$ \\ 1,2,3 Mathematics Education Program Post Graduate IKIP Siliwangi, Cimahi \\ 12desytridamayanti@yahoo.com, ${ }^{2}$ utari.sumarmo@gmail,com, ${ }^{3}$ rippimaya@gmail.com
}

Received: Sep 17 th $^{\text {t } 2018 ; ~ A c c e p t e d: ~ S e p ~ 19 ~}{ }^{\text {th }}, 2018$

\begin{abstract}
This study was a pre test-post test experiment without control group design having a goal to examine the role of Prior Mathematics Ability (PMA), Sylver approach (SA) toward student's mathematical creative thinking ability (MCTA) and Self Regulated Learning (SRL). The study involved 65 eleven grade student, a PMA test, a MCTA test, and SRL scale. The study found that PMA and SA took good role on obtaining student's MCTA, its $\mathrm{N}<\mathrm{Gain}>$ and SRL. On student's MCTA, and its $\mathrm{N}<$ Gain $>$ students getting treatment with SA attained better grades than that of students taught by conventional teaching, and the grades were still at medium level. On SRL, there was no different grades between students on both teaching approaches, and those grades were at fairly good level. The other findings, there was no association between MCTA and SRL, and students performed high perception toward SA.
\end{abstract}

Keyword: mathematical creative thinking, mathematical self regulated learning, Sylver approach

\begin{abstract}
Abstrak
Penelitian ini merupakan penelitian kuasi eksperimen dengan desain pretes dan postes tanpa kelas control yang bertujuan untuk menguji kemampuan awal matematik dengan metode inkuiri model Sylver terhadap kemampuan berpikir kreatif matematik dan kemandirian belajar. Penelitian ini melibatkan 65 siswa kelas XI, yang mengikuti tes kemampuan awal matematik, tes kemampuan berpikir kreatif matematik, dan skala kemandirian belajar. Pada penelitian ini ditemukan bahwa kemampuan awal matematik dan pembelajaran model Sylver memberikan hasil yang baik pada kemampuan berpikir matematik, yaitu N-Gain dan kemandirian belajar. Pada kemampuan berpikir kreatif siswa, peningkatan kemampuan ini pada siswa yang mendapat pembelajaran model Sylver lebih baik disbanding siswa yang mendapat pembelajaran biasa, dan tidak berbeda pada level sedang. Pada kemandirian belajar, tidak terdapat perbedaan hasil dari kedua pembelajaran ini, pada semua level memberikan hasil yang baik. Hasil lain yang didapat adalah tidak terdapat asosiasi antara kemampuan berpikir kreatif matematik dangan kemandirian belajar dan siswa memiliki persepsi yang bagus pada pembelajaran model Sylver.
\end{abstract}

Kata kunci: berpikir kreatif matematik, kemandirian belajar matematik, pembelajaran model Sylver

How to Cite: Damayanti, D.T., Sumarmo, U., \& Maya, R. (2018). Improving Student'sf Creative Thinking Ability and Self Regulated Learning Using Sylver Approach. JIML, 1 (3), 268-278.

\section{INTRODUCTION}

When we observed a mathematics lesson, we found two kinds different student's condition, as such almost of students could solve a rutine mathematics problem without any difficulty, conversely many other students having no power to meet a complex and open-ended problem. The second student's condition ilustrated that students having limited ability on solving creative mathemnatics problem. Whereas, mathematical creative thinking ability (MCTA) was an essential mathematics learning outcome should be improved on student high school. 
The reason of that statement not only caused of it was attached in the goal and vision of teaching mathematics but also it related with daily life. The goal and vision of teaching mathematics, among other were: to improve student's potency to become a critical, creative, logical, accurate, and innovative human (Kurikulum Matematika, 2013). Beside that, creative thinking was a part of life-skill which it was needed for overcoming daily live problems.

Some experts (Martin, 2009, Munandar, 1987, Musbikin, 2006, Pehkonen, 1997, Semiawan, 1984) clarified creative thinking term differently, however they included four main similar components namely: fluency, flexibility, originality, and elaboration. Those components of creative thinking ilustrated high order thinking skill in mathematics which for executing creative thinking, student should possess high motivation, interest, and feeling able to learn and do mathematics well. One of mathematical softskill like that was Self regulated learning (SRL).

Self regulated learning (SRL) itself was not to learn without assistance other people, but to learn which controlled by its self. Some experts (Bandura, Butler, 2002, Corno and Randi, 1999, Hargis, http:/www.smartkidzone. co/, Kerlin, 1992, Paris and Winograd, 1998, Schunk and Zimmerman, 1998, Wongsri, Cantwell, and Archer, 2002, all as cited in Sumarmo (2006), defined SRL differently but they have three similar components, namely: to design selflearning objective; to select strategy; to monitor and to evaluate cognitive and affective processess and to compare them to a certain standard.

Connected with teaching learning, mathematics curriculum of Indonesia suggested that mathematical hardskill such as MCTA and mathematicall softskill namely SRL should be improved on student equally. Moreover, Polya (1980) explained that teacher's role was not only to extend mathematical content, but the most important thing were: to act as a student, to appreciate student's thinking, to help student to construct their new knowledge, to expand their thinking ability, to motivate student to think on his own way, and to help students to $1 \mathrm{e}^{1}$ arn better. To consider the suggestion of Kurikulum Matematika 2013 and Polya's conception, those recomendation offered us to sellect innovative mathematics teaching learning which predicted capable to develop MCTA and SRL accordingly. Observing activities included in the learning process, writers predicted that Sylver teaching approach would fasilitate to improve student's MCTA and SRL.

To analyze deeply the nature of mathematics among other mathematics as a systimatic and structured science, we found that mathematics contained of arranged topics so it suggested that student should master first prerequisite mathematics topics and processes before to learn a new mathematics topic. It implied that for obtaining MCTA student should master first the prior mathematics ability (PMA) of mathematics content that assessed in MCTA test.

Up to now, there were limited studies analyzed MCTS, SRL, SAT accordingly. However, there were some studies analyzed MCTA, SRL, and STA separately. For example, Wardani, S., Sumarmo, U, NISHITANI (2010) reported that student getting treatment with STA attained better grade on MCTA and mathematical disposition.

Concerning PMA, some previous studies among other Aminah, M., Kusumah, Y.K., Suryadi, D. and Sumarmo(2017), Pujiastuti, H. , Kusumah, Y.S. , Sumarmo, U (2014), Setiawati (2014), Nindiasari, H., Kusumah, SK., Sumarmo, U., and Sabandar (2014), Widyaningtiyas 
(2015) by implementing various innovative teaching approaches found that student's PMA took a good role on obtaining various mathematical abilities and soft skills. Those studies pointed out that the higher student's grade of PMA, the studies found the higher student's various mathematical abilities and soft skills.

Refering to those afformentioned arguments, writers were motivated to carry out a study having a goal to examine the role of PMA and STA on attaining student's MCTA and SRL. Then writers posed some research questions as follow.

1. Were MCTA and its normalized gain grades, and SRL grade of students accepting treatment with STA better than the grades of students taught by conventional teaching, observed from entirely students and based on each level of PMA?

2. What were student's difficulties on solving MCTA tasks?

3. Was there any association between MCTA and SRL?

4. Was there any interaction between PMA and teaching approaches toward MCTA and SRL?

5. What were student's believe on STA?

\section{Theoritical Review}

\section{Mathematical Creative Thinking Ability and Self Regulated Learning}

Bassically, mathematical creative thinking ability (MCTA) was an essential ability should be possessed by each member of society in daily live. In our opinion, teachers and experts would agree with statement that high school students should possess MCTA, caused it was attached in the goal of mathematics teaching. Beside that, student as a member of society need also to possess MCTA for solving problems and facing fluctuated situation. That statement was in line with a conception that person who given opportunity to think creatively will grow healthy and able to resist when meet a challence. Conversally, when a person was limited to think creatively he or she would be easy frustated and unsatisfied.

Some experts Munandar (1992), Musbikin (2006), Pehnoken, (1997) defined creative thinking term differently, however they include four main similar components namely: fluency, flexibility, originality, and elaboration. Semiawan (1984) posed that to think creatively as to compile new idea and to apply it in solving problem, and to identify association between unclear ideas. Munandar (1987) detailed components of creative thinking as follow: a) Fluency included: to arouse many ideas, answer, solutions, or questions; to pose many strategies, to consider more than one strategy and its result: b) Flexibility holded: to generate various ideas, answers, or questions, to percieve a problem form different poin of view; to look for different alternatives, to alter an approach or way of thinking; c) Originality are: to bring in a new or unic idea, to consider an unusual way; to compile unusual combination from its parts or elements; d) Elaboration consists: to broaden and to improve an idea or a product; to enlarge or to specify an object, idea, or situation so that became more interesting.

Other expert, Pehnoken (1997) stated creativity as individual's ability to generate something new or unpredictable idea. Musbikin (2006) clarified to think creatively as to iniciate a new idea, to develop a new relationship or unpredictable relationship, to compile non memorized concept, to invent a new solution for previous problem, and to offer a new question.

Other explanation of creative thinking is proposed by Balka as cited in Mann (2005), specified that MCTA loaded convergen and divergen thinking as follow: a) to generate hypothesis, b) to decide pattern of mathematical situation; c) to terminate a deadlock 
thinking by pose a new solution; d) to initiate unsual ideas and to assess its effect; e) to recognize missing information from a given problem; f) to specify general problem into its sub-problems.

To consider the traits of MCTA process, it ilustrated that MCTA was a kind of high order thinking (HOT) in mathematics which it needed high mathematics soft skill for solving MCTA task. One of such mathematics soft skill was self regulated learning (SRL). The meaning of SRL itself was not to learn without assistance from other people, but to learn which controlled by its self. Some experts (Butler, 2002, Corno and Randi, 1999, Kerlin, 1992, Paris and Winograd, 1998, Schunk and Zimmerman, 1998, Wongsri, Cantwell, and Archer, 2002, all as cited in Sumarmo, 2006), defined SRL differently but they attached three similar components, namely: to design self-learning objective; to select strategy; to monitor and to evaluate cognitive and affective processess and to compare them to a certain standard as cited in Sumarmo (2006). Some definitions of SRL among other things were as follow: a) SRL as a process of self designing and monitoring cognitive and affective processess in solving academic task (Hargis, http:/www.jhargis.co/ and Kerlin, 1992, as cited in Sumarmo (2006); b) SRL as a human personality and ability to monitor self behavior and as human's hard-work personality (Bandura as cite in Sumarmo, 2006); c) SRL as learning process caused effect of thinking, feeling, strategy, and self behavior oriented on attaining of a goal by Schunck, D.H., \& Zimmerman (1998), as cited in Sumarmo (2006); d) SRL as cycle of recursive cognitive activities consisted: to analyze task, to select, to adopt, to find strategy approach for achieving the goal of a task, and to monitor outcome of conducted strategy.

Wongsri, Cantwell, Archer as cited in Sumarmo (2006) proposed similar term of SRL that was self-direction on learning or SDL as learning process where a person designed self learning responsibly, implementing, and evaluating his or her learning process. Other writter, Hoban, Sersland, Raine (as cited in Wongsri, Cantwell, Archer, 2002, as cited in Sumarmo (2006) state that SDL related to self-efficacy such as individual's opinion on her or his own ability in a certain academic area.

Some experts propose suggestion for improving self regulated learning among other as follow. Butler's suggestion (as cited in Sumarmo (2006) are: Help student to excecute the cycle of SRL flexibly and adaptively. Other suggestion is proposed by Schunk, (as cited in Sumarmo (2006) namely: Create condusive learning environment and avoid irrelevant student's activity; help students to manage their time; promote self confidence for being uneasy panic. Other writter, Sauri (2012) proposes that SRL similar to value and character education couldn't be taught directly as to teach mathematics, but SRL should be improved through four ways such as: Make student realize on the meaning and the importance of having SRL; Perform teacher to behave the wished SRL; Familiarize students to behave the wished SRL; Carry out integrated and continous mathematics teaching-learning process.

Then, based on ideas of those experts (Butler, Corno and Randi, Hargis, Kerlin, Paris and Winograd, Schunk and Zimmerman, Wongsri, Cantwell, and Archer as cited in Sumarmo (2006) then summarized the indicators of SRL such as: a) To posses intrinsic learning initiative and motivation, b) To perform habit to diagnose learning need; c) to determine learning objective and target, d) To monitor, to manage, and to control own learning; e) to consider that a difficulty as a challenge; f) to use and to seek relevant sources; g) to choice and to apply learning strategy; h) to evaluate learning process and learning outcomes; i) to possess self concept and self efficacy. Yang (Hargis, http:/www.jhargis.co/, as cited in 
Sumarmo (2006) found that students with high SRL: tend to learn better in their own control, able to control, to evaluate, and to manage their learning effectively, to save their time in solving their tasks, and to manage their time efficiently.

\section{Sylver Model of Teaching Approach}

Wardani (2012) described Inquiry Learning Sylver Model has phases as follows: providing situations related to the real world or problems that cause students' curiosity. With the knowledge and experience, students make individual observations (if classical learning), or groups (if learning in groups), on the problems given. From observations, students are required to raise problems or questions from existing problems and share with friends. Then they can provide temporary answers to the problems raised by the teacher or students. Students discuss and identify several possible answers and test the correct answers. In this activity students are directed to solve problems in various ways. After that, students or teachers can re-submit a new problem from the problem. Students can dig deeper into new problems that arise, then solve them. So on. until students can optimize their potential in developing their mathematical problem solving abilities.

\section{Related Studies}

Recently, there were limited studies to examine student's MCTA and SRL and ISM accordingly. However there were some studies analyzed those variables separately. For example, Wardani, S., Sumarmo, U, NISHITANI (2010) found that student accepting Sylver teaching approach obtained, better grades on MCTA and mathematical disposition than the grades of student taught by conventional teaching. However, student's grade on MCTA were at medium level and students still posed difficulties on solving MCTA. Beside that, Wardani, S., Sumarmo, U, NISHITANI (2010) reported that there was asociation between MCTA and mathematical disposition.

Concerning PMA, some studies by Aminah, M., Kusumah, Y.K., Suryadi, D. and Sumarmo (2017), Nindiasari, H., Kusumah, SK., Sumarmo, U., and Sabandar (2014), Pujiastuti, H. , Kusumah, Y.S. , Sumarmo, U (2014), Setiawati (2014), Widyaningtiyas (2015) reported that PMA and various innovative teaching approaches confered a good role on obtaining various mathematical abilities and soft skills. That statement was supported by the fingdings that the higher student's grade on PMA, the student obtained higher grades on various mathematical abilities and soft skills.

\section{Method and Design of Study}

This study was a pre test-post test experiment witout control group design which having a goal to analyze the role of PMA and Inquiry Sylver Model (ISM) on students' mathematical creative thinking ability (MCTA) and SRL. The study involved 65 eleventh grade students, an objective test PMA, an esay MCTA test, a SRL scale, and a student's opinion toward SMA. The MCTA test consisted of 5 items, and by using Hendriana and Sumarmo (2014), as reference it was obtained charactristic MCTA test as follow: reliability test was $\mathrm{r}=.51$; item validity were $.43 \leq \mathrm{IV} \leq .72$; discriminant power were $.22 \leq \mathrm{DP} \leq .53$, and difficulty index were $.53 \leq \mathrm{DI} \leq .61$. In the following, we attached sample items of MCTA test, sample of SRL scale.

\section{Sample item of mathematical creative thinking test}

a. $\quad A=\left(u_{1} u_{4} u_{7} u_{2} u_{5} u_{8} u_{3} u_{6} u_{9}\right)$ with $u_{n}$ is the arithmetic sequence. Given that the 11 th and 16 th terms of the arithmetic sequence are 21 and 31 respectively, $A^{-1}$ is the inverse of the matrix. A specify the detector $A^{-1}$ in the way you know. Give your reason!

b. Make a story about everyday problems which is a three-variable linear equation into the form of the problem solving matrix.

\section{Sample item of Self Regulated Learning (SRL) Mathematics Scale}


Note: SA: Strongly agree

$$
\text { A : Agree }
$$

DA: Disagree

SDA: Strongly disagree

Table 1. SRL Scale

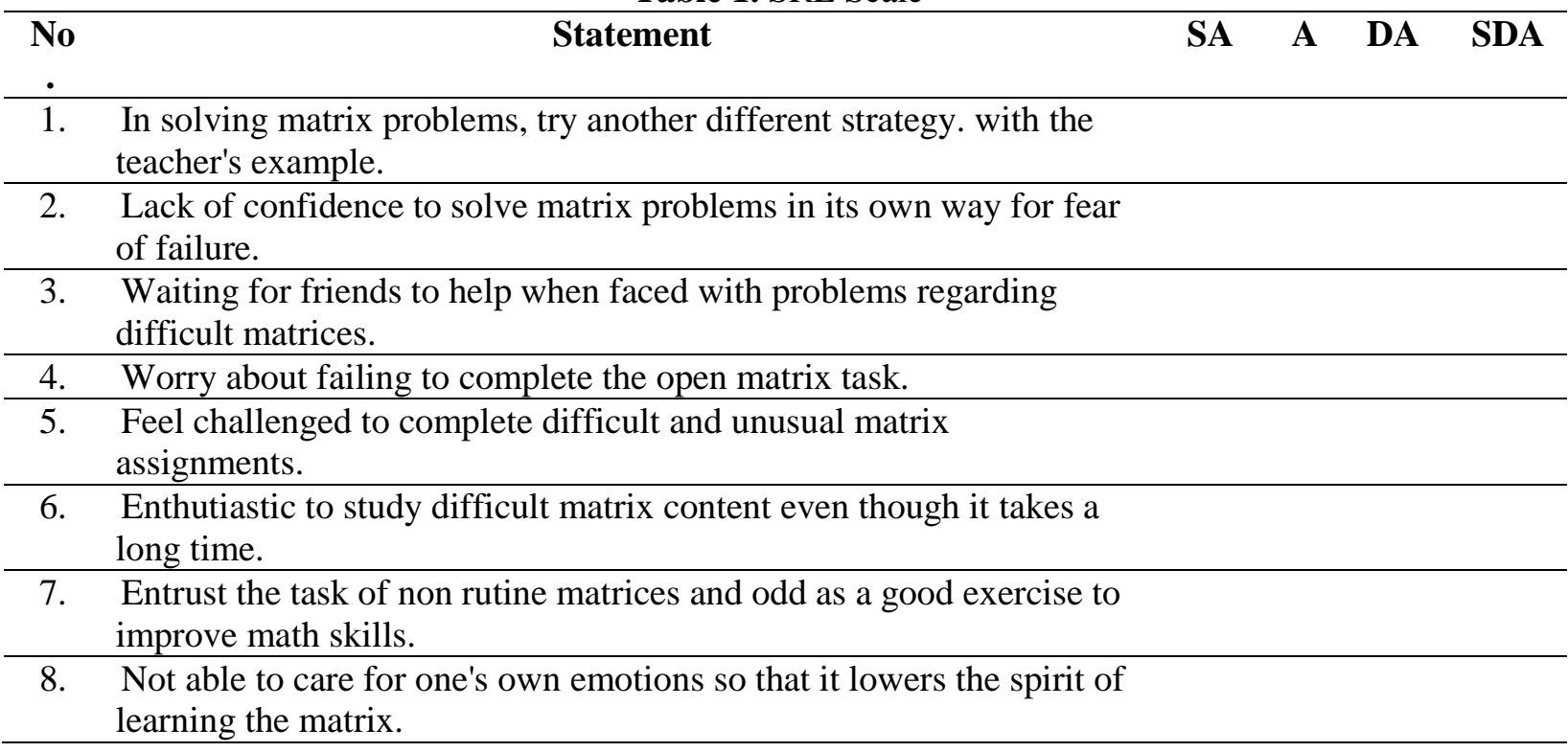

\section{Findings and Discussion}

Description of MCTA, and SRL of students was attached in Table 2.

Table 2. Description of Students' Mathematical Creative Thinking Ability, Self Regulated Learning in Both Teaching Approaches

\begin{tabular}{|c|c|c|c|c|c|c|c|c|c|c|}
\hline \multirow[b]{2}{*}{$\begin{array}{c}\text { Varia- } \\
\text { bles }\end{array}$} & \multirow[b]{2}{*}{ PMA } & \multirow[b]{2}{*}{ Stat } & \multicolumn{4}{|c|}{ Inquiri method Silver Model } & \multicolumn{4}{|c|}{ Conventional Teaching (ET) } \\
\hline & & & $\begin{array}{l}\text { Pre- } \\
\text { Test }\end{array}$ & $\begin{array}{l}\text { Post- } \\
\text { Test }\end{array}$ & $\begin{array}{c}\mathrm{N} \\
\text { Gain }\end{array}$ & $\mathrm{n}$ & $\begin{array}{l}\text { Pre- } \\
\text { Test }\end{array}$ & Post-Test & $\begin{array}{c}\mathrm{N} \\
\text { Gain }\end{array}$ & $\mathrm{n}$ \\
\hline \multirow{12}{*}{ MCTA } & \multirow{3}{*}{ High } & $\bar{X}$ & 4.27 & 28.18 & \multirow{2}{*}{.62} & \multirow{3}{*}{11} & 425 & 21,75 & \multirow{2}{*}{.40} & \multirow{3}{*}{8} \\
\hline & & $\%$ & 10.67 & 70.45 & & & 10,62 & 54.37 & & \\
\hline & & SD & 1.35 & 2.27 & .06 & & 1,16 & 4,37 & .13 & \\
\hline & \multirow{3}{*}{ Medium } & $\bar{X}$ & 2.12 & 22.76 & \multirow{2}{*}{.61} & \multirow{3}{*}{17} & 3.63 & 19.25 & \multirow{2}{*}{.24} & \multirow{3}{*}{16} \\
\hline & & $\%$ & 5.3 & 56.90 & & & 9.07 & 48.12 & & \\
\hline & & SD & 1.16 & 4.37 & .13 & & 1.50 & 3.28 & .07 & \\
\hline & \multirow{3}{*}{ Low } & $\bar{X}$ & 7.20 & 21.00 & \multirow{2}{*}{.50} & \multirow{3}{*}{5} & 2.38 & 17.13 & \multirow{2}{*}{.31} & \multirow{3}{*}{8} \\
\hline & & $\%$ & 18,00 & 52.5 & & & 5.95 & 42.82 & & \\
\hline & & SD & 1.64 & 3.46 & .04 & & 1.60 & 1.75 & .04 & \\
\hline & \multirow{3}{*}{ Total } & $\bar{X}$ & 3,61 & 23.64 & \multirow{2}{*}{.59} & \multirow{3}{*}{33} & 3.47 & 19.34 & \multirow{2}{*}{.34} & \multirow{3}{*}{32} \\
\hline & & $\%$ & .92 & 59.10 & & & 8.67 & 48.35 & & \\
\hline & & SD & 2.34 & 3.77 & .07 & & 1.57 & 3.60 & .07 & \\
\hline \multirow{9}{*}{ SRL } & \multirow{3}{*}{ High } & $\bar{X}$ & & 112.5 & & \multirow{3}{*}{11} & & 109.63 & & \multirow{3}{*}{8} \\
\hline & & $\%$ & & 93.7 & & & & 91.35 & & \\
\hline & & SD & & 2.62 & & & & 2.26 & & \\
\hline & \multirow{3}{*}{ Medium } & $\bar{X}$ & & 102.5 & & \multirow{3}{*}{17} & & 100.69 & & \\
\hline & & $\%$ & & 85.42 & & & & 83.90 & & 16 \\
\hline & & SD & & 4.14 & & & & 3.00 & & \\
\hline & & $\bar{X}$ & & 93.20 & & & & 91.38 & & \\
\hline & Low & $\%$ & & 77.67 & & 5 & & 76.15 & & 8 \\
\hline & & SD & & 1.64 & & & & 3.38 & & \\
\hline
\end{tabular}


274 Damayanti, Sumarmo \& Maya, Improving Student'sf Creative Thinking Ability and Self Regulated Learning Using Sylver Approach

\begin{tabular}{|c|c|c|c|c|c|}
\hline \multirow{3}{*}{ Total } & $\bar{X}$ & 104.45 & \multirow{3}{*}{33} & 100.59 & \multirow{3}{*}{32} \\
\hline & $\%$ & 87.04 & & 83.83 & \\
\hline & SD & 7.40 & & 7.15 & \\
\hline
\end{tabular}

Note:

MCTA: Mathematical critical thinking ability,

$\mathrm{SRL}$ : self regulated learning in mathematics
Ideal Score: 40

Ideal Score: 120

From Table 2, in pre-test it found that there was no difference of MCTA of students in both teaching approaches, and the grades were at very low level. Nevertheles, after learning process, on MCTA, its gain $(\mathrm{N}<\mathrm{G}>)$, and SRL students accepting treatment with Inquiry Sylver Model (ISM) attained better grades than the grades of students taught by conventional teaching. The MCTA grade of student getting treament with ISM was at medium level, whereas the grade of students taught by conventional teaching was at low level. Even if, on SRL students on both teaching approaches were clasified at good grade level. Finding on MCTA of this study was similar to the findings of some previous studies (Rohaeti \& Budiyanto, 2014, Saputri, 2015, Sumarmo, et al, 2012, Widyaningtiyas, 2014) that students taught by PBL obtained better grades than students taught by conventional teaching. are at low level. The testing hypothesis of those data using Mann Whitney test was attached in Tabel 2.

Table 3. Testing Hypothesis of Mean Difference of Mathematical Creative Thinking Ability, and Self Regulated Learning on Both Teaching Approaches

\begin{tabular}{|c|c|c|c|c|c|c|c|}
\hline Variables & $\begin{array}{l}\text { Teaching } \\
\text { Approach }\end{array}$ & $\overline{\bar{x}}$ & SD & $\mathrm{N}$ & $\begin{array}{l}\text { Sig (2- } \\
\text { tailed). }\end{array}$ & $\begin{array}{l}\text { Sig(1- } \\
\text { tailed). }\end{array}$ & Interpretation \\
\hline \multirow[b]{2}{*}{ MCTA } & ISM & 23.64 & 3.77 & 33 & \multirow[t]{2}{*}{.000} & \multirow[t]{2}{*}{$.000<.05$} & MCTA $_{\text {ISM }}>$ \\
\hline & CT & 19.34 & 3.60 & 32 & & & MCTA $_{\mathrm{CT}}$ \\
\hline \multirow{2}{*}{$\begin{array}{l}\text { N-Gain } \\
\text { MCTA }\end{array}$} & ISM & .59 & .07 & 33 & \multirow[t]{2}{*}{.000} & \multirow[t]{2}{*}{$.000<.05$} & $\mathrm{~N}$ Gain MCTA $\mathrm{ISM}_{\mathrm{I}}>$ \\
\hline & $\mathrm{CT}$ & .34 & .07 & 32 & & & N-Gain MCTA \\
\hline \multirow[b]{2}{*}{ SRL } & ISM & 104.45 & 7.40 & 33 & \multirow[t]{2}{*}{.036} & \multirow[t]{2}{*}{$.018<.05$} & $\mathrm{SRL}_{\mathrm{ISM}}$ and $\mathrm{SRL}_{\mathrm{CT}}$ \\
\hline & CT & 100.59 & 7.15 & 32 & & & \\
\hline
\end{tabular}

Note: Mathematical Creative Thinking Ability Self Regulated Learning

Ideal score MSE :122

When we observed deeply student's grades on MCTA and on SRL in each level of PAM, study found that the higher students' PMA so student obtained the higher grades on MCTA, its $\mathrm{N}\langle\mathrm{G}\rangle$, and SRL as well. This finding was similar to some previous studies (Aminah, et.all. 2017, Kurniati, et.all. 2015, Kurniawati, et.all. 2014, Nindiasari, et.all, 2014, Pujiastuti, et.all. 2014, Setiawati, 2014, Widyaningtiyas, 2015), that PMA gave good role on improving various mathematics abilities. Those findings supported statement that PMA confered good role on improving student's MCTA and on obtaining student's SRL. That statement implied that teracher and or researcher should examined student's PMA before to teach new mathematics topic, or to carry out study on a new topic.

Based on Table 2, student's grades on MCTA were at low-medium level. It indicated that student realized difficulties on solving MCTA problem. Those student's difficulties was ilustrated on Table 4. In fact, almost mean scores of each item MCTA test on both teaching approaches were les than $60 \%$ (except No 4 and No 5 of Inquiry Sylver Model. Those findings ilustrated that many students of both teaching approaches still realized difficulties in solving MCTA task. 
Further analysis, was concerning association between MCTA and SRL. That association was analyzed by using contigency table such as in Table 4 and by using $\chi^{2}$ testing. The analysis obtained value $\chi^{2}=3.739^{\mathrm{a}}$ and sig. $(2$ tailed-., $163>.005)$. This meant that there was no association between MCTA and SRL

Table 4. Mean Score of Each Item of Mathematical Creative Thinking Test of Students In Both Teaching Approaches

\begin{tabular}{lccccccc}
\hline Teaching & Stat.Desc & No.1 & No 2. & No.3 & No.4 & No.5 & Entirely \\
\cline { 2 - 8 } Approach & Ideal score & 8 & 8 & 8 & 8 & 8 & 50 \\
\hline Inquiry Sylver & $\overline{\mathrm{X}}$ & 4.21 & 3.94 & 4.61 & 5.91 & 4.97 & 23.64 \\
\cline { 2 - 8 } Model & \% of IS & 52.65 & 49.24 & 57.58 & 73.86 & 62.12 & 59.10 \\
\hline Conventional & $\overline{\mathrm{X}}$ & 3.50 & 3.34 & 3.34 & 4.53 & 4.16 & 19.34 \\
\cline { 2 - 8 } Teaching & \% of IS & 43.75 & 41.80 & 48.44 & 48.44 & 55.55 & 48.35 \\
\hline
\end{tabular}

Table 5. Contigency Table of Mathematical Creative Thinking Ability and Self Regulated Learning in Sylver Inquiry Model Class

\begin{tabular}{ccccc}
\hline MCTA & High & Medium & Low & Total \\
\hline High & 3 & 1 & 0 & 4 \\
\hline Medium & 8 & 10 & 6 & 24 \\
\hline Low & 1 & 3 & 1 & 5 \\
\hline Total & 12 & 14 & 7 & 33 \\
\hline
\end{tabular}

Next analysis was concerning interaction between PAM and teaching approaches toward MCTS and SRL. The interaction were analysed by using two path ANOVA such as in Table 6 and Table 7, and then were completed with the graph of interaction that ilustrated in Figure 1 and Figure 2.

Table 6. Two Path ANOVA of Interaction Between PAM and Teaching Approaches toward MCTA

\begin{tabular}{lcccccc} 
Source & $\begin{array}{c}\text { Type III Sum of } \\
\text { Squares }\end{array}$ & df & $\begin{array}{c}\text { Mean } \\
\text { Square }\end{array}$ & F & Sig. & $\begin{array}{c}\text { Partial Eta } \\
\text { Squared }\end{array}$ \\
\hline Corrected Model & $504.145^{\text {a }}$ & 5 & 100.829 & 9.151 & .000 & .437 \\
Intercept & 24768.208 & 1 & 24768.208 & 2247.948 & .000 & .974 \\
kelas & 211.026 & 1 & 211.026 & 19.153 & .000 & .245 \\
level_kam & 193.775 & 2 & 96.888 & 8.793 & .000 & .230 \\
kelas * level_kam & 2.496 & 2 & 1.248 & .113 & .893 & .004 \\
Error & 650.070 & 59 & 11.018 & & & \\
Total & 31265.000 & 65 & & & & \\
\hline Corrected Total & 1154.215 & 64 & & & \\
a. R Squared =,437 (Adjusted R Squared = .389)
\end{tabular}

Table 7. Two Path ANOVA of

Interaction Between PAM and Teaching Approaches toward SRL

\begin{tabular}{lcccccc}
\hline Source & $\begin{array}{c}\text { Type III Sum of } \\
\text { Squares }\end{array}$ & df & $\begin{array}{c}\text { Mean } \\
\text { Square }\end{array}$ & F & Sig. & $\begin{array}{c}\text { Partial Eta } \\
\text { Squared }\end{array}$ \\
\hline Corrected Model & $2971.229^{\mathrm{a}}$ & 5 & 594.246 & 57.967 & .000 & .831 \\
Intercept & 561758.717 & 1 & 561758.717 & 54798.260 & .000 & .999 \\
kelas & 64.889 & 1 & 64.889 & 6.330 & .015 & .097 \\
level_kam & 2658.957 & 2 & 1329.479 & 129.688 & .000 & .815 \\
kelas* level_kam & 2.975 & 2 & 1.488 & .145 & .865 & .005 \\
Error & 604.832 & 59 & 10.251 & & & \\
\hline
\end{tabular}



Self Regulated Learning Using Sylver Approach

\begin{tabular}{lcc}
\hline Total & 687200.000 & 65 \\
Corrected Total & 3576.062 & 64 \\
a. $\quad$ R Squared $=.831$ (Adjusted R Squared $=.817)$ \\
\hline
\end{tabular}

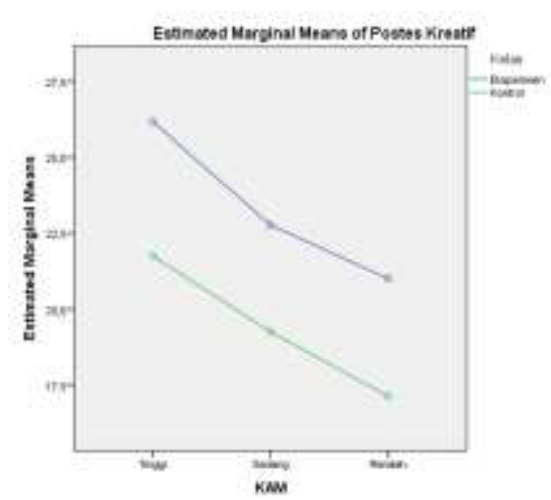

Figure 1.

Interaction Between PAM and Teaching Approaches toward MCTA

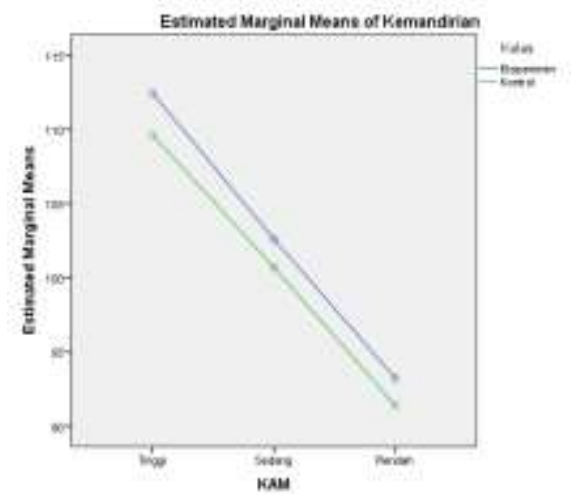

Figure 2

Interaction Between PAM and

Teaching Approaches toward SRL

Based on Table 6 and Table 7, study found sig $=.893$ and sig $=.865$ successively for interaction between PAM and teaching approaches (Sylver Inquiry Model and conventioanl teaching) toward MCTA and toward SRL. Those findings indicated that there were no interaction between PAM and teaching approaches toward MCTA and toward SRL. That interpretation was supported by the graph of those interaction as in Figure 1 and Figure 2, that there were no intersection between the lines. It meant that Inquiry Sylver Model confered the greatest role than PMA and conventional teaching on improving MCTA and obtaining SRL.

The study found that students on both classess obtained MCTA in each item test at low grade level (less than 60\% out of ideal score) Seemingly, mathematical creativethinking problems were difficult tasks for most yunior high school students. This findings was similar to findings of other previous studies .

\section{Conclusion, Implication, and Suggestion Conclusion}

Based on findings and discussion, the study derived conclusion as follow.

In fact, inquiry Sylver model confered the best role than student's previous mathematics ability and conventional teaching on improving students' mathematical creative thinking ability, its gain, and student's self regulated learning. However on mathematical creative thinking ability students'grades were still at low-medium, many students realyzed difficulties on solving mathematical creative thinking ability tasks. Conversely, on self regulated learning, students accepted inquiry Sylver model obtained higher grade than the grade of student taught by conventional teaching, and both grades were at good level.

The other conclusion were that, there was no association between mathematical creative thinking ability and self regulated learning, and there were no interaction between previous mathematics ability and teaching approaches toward mathematical creative thinking ability and self regulated learning. Beside that, students performed more active learning during inquiry Sylver model compared during conventional teaching.

\section{Suggestion}


Based on the conclusion and discussion the study proposed some suggestion as follow. The students' grade on MCTA in both classes were at low-medum level. For obtaining mathematical creative thinking abilty, students should master firstly the prerequisite of mathematical process and content of mathematical creative thinking test. So, before teacher were going to explain a new mathematics topic or content or to conduct study on any mathematics ability, it is suggested teacher to examine students' abilities of its prerequisite firstly, students should be motivated to select and to solve more exercises by theirselfes on mathematical creative thinking ability. In order students attained meaningfull mathematical creative thinking ability, it was suggested students asked to write the formulas and rules which used on each step in solving the problems as well.

\section{REFERENCES}

Aminah, M., Kusumah, Y.K., Suryadi, D. and Sumarmo, U. (2017). Enhancing Students' Mathematical Logical Thinking Ability and Self Regulated Learning By Using Metacognitive Teaching-Learning. Paper Published in International Journal of Instruction, 11(3).

Mann, E. L. (2005). Mathematical Creativity and School Mathematics: Indicators of Mathematical Creativity in Middle School Students. Connecticut: University of Connecticut.

Munandar, U. (1987). Creativity and Education. Jakarta: Disertasi Doktor, Universitas Indonesia: Departemen Pendidikan dan Kebudayaan.

Munandar, U. (1992). Mengembangkan Bakat dan Kreativitas Anak Sekolah.

Musbikin, I. (2006). Mendidik Anak Kreatif ala Einstein. Yogyakarta: Mitra Pustaka.

Nindiasari, H., Kusumah, SK., Sumarmo, U., and Sabandar, Y. (2014). Pendekatan metakognitif untuk meningkatkan kemampuan berpikir Reflektif Matematis Siswa SMA. Edusentris Jurnal Ilmu Pendidikan Dan Pengajaran, 1(1), 80-90.

Pehnoken, E. (1997). The State-of-Art in Mathematical Creativity. Zentralblatt für Didaktik der Mathematik (ZDM). The International Journal on Mathematics Education. [Online] Tersedia:Http://Www.Emis.de/Journals/ZDM/Zdm.

Polya, G. (1980). On Solving Mathematical Problems in High School. New Jersey: Princeton Univercity Press.

Pujiastuti, H. , Kusumah, Y.S. , Sumarmo, U, A. J. D. (2014). Pujiastuti, H. , Kusumah, Y.S. , Sumarmo, U, Afgani J. D (2014). "Inquiry Cooperation Model Enchanching Yunior High School Students' Mathematical Problem Solving Ability" Paper published in International Journal of Contemporary Educational Research. (IJCE. Paper Published in International Journal of Contemporary Educational Research (IJCER), 1(1).

Sauri, S. (2012). Membangun Karakter Bangsa melalui Pembinaan Profesionalisme Guru Berbasis Pendidikan Nilai. Jurnal Pendidikan Karakter., 2(2).

Schunck, D.H., \& Zimmerman, B. J. (1998). Introduction to the Self Regulated Learning (SRL) Cycle.No Title.

Setiawati, E. (2014). Mengembangkan Kemampuan Berpikir Logis, Kreatif, dan Habits of Mind Matematis melalui Pembelajaran Berbasis Masalah. Bandung: Unpublished Disertation at Post Graduate UPI.

Sumarmo, U. (2006). Kemandirian belajar: Apa, mengapa dan bagaimana dikembangkan pada peserta didik" Paper presented at Seminar of Mathematics Education in Department of Mathematics, Faculty of Mathematics and Science, State University of Yogyakarta. Makalah dimuat dalam Sur. Bandung: Jurusan Pendidikan Matematika FPMIPA UPI.No Title.

Wardani, S., Sumarmo, U, NISHITANI, I. (2010). Improving Students' Mathematical Creative Ability and Disposition by using Sylver' Model Approach. Paper Published in 
278 Damayanti, Sumarmo \& Maya, Improving Student'sf Creative Thinking Ability and Self Regulated Learning Using Sylver Approach

Research in Educational and Development. Gunma University, 58, 9-22.

Wardani. (2012). SILVER MODEL INQUIRY LEARNING FOR DEVELOPING MATHEMATICAL PROBLEM SOLVING PROBLEMS AND DISPOSITION OF MIDDLE SCHOOL STUDENTS FOR HISTORY. Journals Journal of Mathematics Education, 1(1).

Widyaningtiyas, R. (2015). Pengaruh Pendekatan Pembelajaran Berbasis Masalah terhadap Kemampuan dan Disposisi Berpikir Kritis dan Kreatif Matematis Siswa SMA. Part of Disertation, that is: Widyaningtias,R., Kusumah, Y.S., Sumarmo, U. Sabandar, Y. (2017), "The Impact of Problem Base. Journal of Mathematics Education, 6(2), 107116. 